\title{
El análisis de redes: qué es, orígenes, crecimiento y futuro
}

\section{Qué es el análisis de redes}

$\mathrm{E}$ análisis de redes o análisis de redes sociales (social network analysis) es la solución a muchos problemas de investigación. El análisis de redes es una aproximación teórica y metodológica que señala que lo más importante es estudiar las relaciones, enlaces o contactos entre los actores ${ }^{1}$. Cualquier tipo de relación puede ser materia de estudio del análisis de redes: relaciones entre personas u organizaciones, comunicaciones, transferencias de conocimientos, traspasos económicos e, incluso, vínculos neuronales.

Vivimos en un mundo cada vez más interconectado: hoy en día recibimos más e-mails al día que hace años llamadas telefónicas, absorbemos cada vez más información y esta procede de muchísimas fuentes. Las organizaciones se han extendido mediante alianzas de todo tipo y los países están cada vez más abiertos y relacionados entre sí. Sin embargo, nuestro cerebro no es capaz de registrar y analizar toda esta inmensa cantidad de relaciones, contactos y enlaces. Piense por un momento en todos sus compañeros de trabajo, y después en todos los familiares de sus compañeros de trabajo, y después en todos los compañeros de trabajo de los familiares de sus compañeros de trabajo, y en las posibles relaciones entre ellos. Imposible visualizar y comprender esta gran cantidad de datos sobre personas y relaciones. De acuerdo con el psicólogo Robin Dunbar ${ }^{2}$ nuestro cerebro, a pesar de que tenga miles de contactos, tiene la limitación de registrar significativamente solo 150 relaciones. Esta "limitada" capacidad cerebral contrasta con el ser "hiperconectado" de hoy en día, por lo que son necesarias herramientas de análisis si deseamos investigar las relaciones entre un conjunto de actores. El análisis de redes es la aproximación que permite procesar, examinar y visualizar un amplio conjunto de actores y los posibles enlaces entre ellos. Las redes han existido siempre, lo que no ha existido siempre es la forma de analizarlas. Veamos las funcionalidades y algunos ejemplos.

El análisis de redes permite entre varios aspectos:

- Analizar qué tan cohesionados están los actores de un estudio, por ejemplo, si las elites empresariales están unidas o fragmentadas ${ }^{3}$.

- Identificar quiénes son los líderes y qué posición ocupa cada actor en la red, por ejemplo, para averiguar quiénes son los intermediarios en las redes de narcotráfico ${ }^{4}$.

- Detectar subgrupos o comunidades de actores en función de sus relaciones, por ejemplo, a fin de conocer las comunidades empresariales y su ubicación geográfica en la red mundial de empresas ${ }^{5}$.

1 Rodríguez, J. A. (2005). Análisis Estructural y de Redes. Madrid: cis.

2 Dunbar, R. I. M. (1993). Coevolution of neocortical size, group size and language in humans. Behavioral and Brain Sciences, 16(04), 681-694. http://doi.org/10.1017/S0140525X00032325.

3 Cárdenas, J. (2015). Are Latin America's corporate elites transnationally interconnected? A network analysis of interlocking directorates. Global Networks, 15(4), 424-445. http://doi.org/10.1111/glob.12070.

4 Garay, L. J., y Salcedo-Albarán, E. (2012). Narcotrafico, corrupcion y estados. Como las redes ilicitas han reconfigurado las instituciones en Colombia, Guatemala y Mexico. Ciudad de México: Grijalbo.

5 Heemskerk, E. M., y Takes, F. W. (2015). The Corporate Elite Community Structure of Global Capitalism. New Political Economy, 0(0), 1-29. http://doi.org/10.1080/13563467.2015.1041483. 
- Comprobar si las relaciones tienen un impacto en el comportamiento, o qué variables explican la construcción de redes, como, por ejemplo, si los contactos sociales influyen en la obesidad ${ }^{6}$.

En resumen, el análisis de redes resuelve inquietudes que impliquen relaciones, enlaces, contactos, transferencias, contagios o cualquier tipo de pauta relacional.

\section{Orígenes del análisis de redes sociales}

Este paradigma teórico y metodológico nace de la contribución de diversas disciplinas, pero sobre todo de las ciencias sociales? ${ }^{7}$. Desde la psicología, Jacob Moreno ${ }^{8}$ se percató de la importancia de las relaciones sociales entre las personas que acudían a sus terapias y decidió representarlas como nodos y líneas, creando sociogramas. Desde la antropología, la escuela de Manchester encabezada por John Barnes ${ }^{9}$ destacó la relevancia de las redes, incluso por encima de la cultura, con el propósito de comprender el comportamiento de los inmigrantes. Desde la sociología, Harrison White ${ }^{10}$ trató de darle consistencia relacional a conceptos tales como estructura, rol social o mercado. Su alumno Granovetter ${ }^{11}$ enfatizó la relevancia de los vínculos débiles y la inserción de la acción económica en redes sociales. Otros sociólogos destacaban que las relaciones son constituyentes de capital social ${ }^{12}$. A todas estas contribuciones de las ciencias sociales les faltaba un compañero: la teoría de grafos de las matemáticas. El uso de la teoría de grafos para definir y analizar las redes sociales ha permitido que se puedan analizar de manera sistemática y matemática amplios conjuntos de relaciones entre actores. El desarrollo de programas informáticos que procesen gran cantidad de datos en forma de nodos (actores) y líneas (relaciones) ha posibilitado que los investigadores puedan responder preguntas sobre redes como el grado de cohesión o fragmentación, la identificación de líderes o poderosos en función de los contactos, la detección de comunidades internas y las dinámicas de la formación y cambio de las redes. El análisis de redes ha pasado de ser un ejercicio metodológico a una ciencia.

\section{Crecimiento del análisis de redes}

Entre el 2000 y el 2015, ha crecido el número de investigaciones que emplean análisis de redes sociales. Según un análisis de los artículos científicos que usan análisis de redes sociales, se ha pasado de catorce artículos en el 2000, a 838 en 2014 (figura 1). Además, desde la década de 1990, se ha institucionalizado la investigación en análisis de redes. Hay cursos sobre análisis de redes en universidades de todo el mundo, incluso es parte de los planes de estudio en programas de ciencias sociales. Existen revistas académicas especializadas en análisis de redes y las investigaciones que lo aplican se publican en revistas de alto impacto. En la década de los noventa, se formó la International Network of Social Network Analysis, la cual integra a los investigadores de análisis de redes. Más allá del sector académico, el análisis de redes se emplea en el diseño de políticas, como, por ejemplo, las redes de conocimiento científico que diagnostican el estado de la producción científica y ayudan a tomar decisiones sobre las políticas de

6 Christakis, N. A., y Fowler, J. H. (2007). The Spread of Obesity in a Large Social Network over 32 Years. New England Journal of Medicine, 357(4), 370-379. doi: http://doi.org/10.1056/NEJMsa066082.

7 Scott, J. (1991). Social Network Analysis. London: Sage.

8 Moreno, J. L. (1934). Who Shall Survive? Washington: Nervous and Mental Diseases Publishing.

9 Barnes, J. A. (1954). Class and committees in a Norwegian island parish. Human Relations, (7), 39-58.

10 White, H. C. (1981). Where Do Markets Come From? American Journal of Sociology, 87, 47-517.

11 Granovetter, M. S. (1973). The Strength of Weak Ties. The American Journal of Sociology, 78(6), 1360-1380.

12 Burt, R. (1982). Toward a Structural Theory of Action. Academic Press: Nueva York; Coleman, J. (1988). Social Capital in the Creation of Human Capital. American Journal of Sociology, 94, 95-120. 
investigación y desarrollo. Se ha revelado que el análisis de redes es empleado por la Agencia de Seguridad Nacional de Estados Unidos para registrar y analizar las comunicaciones electrónicas, y por departamentos policiales para detectar actores centrales en las transferencias bancarias. También las organizaciones emplean análisis de redes para realizar diagnósticos internos y conocer su entorno (organizational network analysis). Aunque con distintas finalidades, todos estos estudios buscan vislumbrar y analizar conjuntos de relaciones entre actores, es decir, redes.

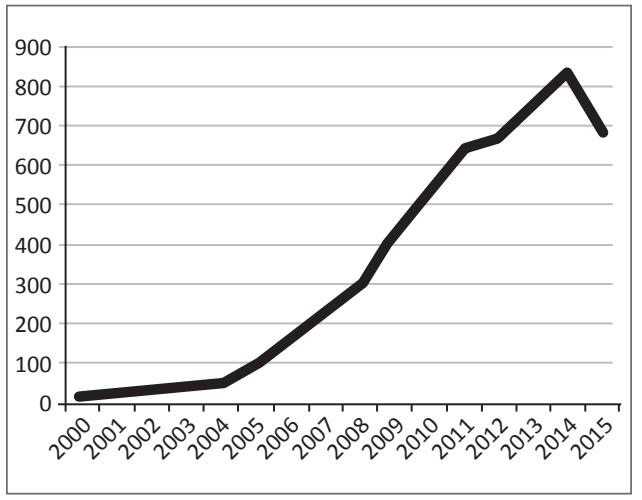

Figura 1. Artículos científicos que contienen la palabra clave "social network analysis" en el abstract entre el 2000 y 2015. Elaboración propia a partir de Scopus (2016).

\section{Futuro del análisis de redes}

El futuro del análisis de redes es prometedor debido al auge de las teorías que enfatizan que el mundo actual es muy interconectado, y que las relaciones sociales tienen un impacto cada vez mayor en temas como la salud ${ }^{13}$, la felicidad ${ }^{14}$, el crimen ${ }^{15} \mathrm{e}$, incluso, la $\mathrm{paz}^{16}$. Además, varios programas informáticos como UCINET, Pajek, Gephi, o los paquetes de $\mathrm{R}$ de análisis de redes permiten procesar grandes cantidades de datos (big data), por lo que cumplen con la demanda para analizar la enorme cantidad de información disponible hoy en día. Sin embargo, esta ventaja también puede llegar a convertirse en una mala práctica si no es acompañada por interpretaciones o teoría. Por ejemplo, han proliferado los estudios sobre las conversaciones en Twitter usando análisis de redes, pero los resultados en ocasiones no pasan de la mera visualización de la red y la identificación de comunidades de nodos. Si el análisis de redes se convierte solo en una herramienta informática y no está acompañada de comprobación de hipótesis o de generación de teorías, perderá su esencia, esto es, entender las relaciones entre los actores. El análisis de redes sociales no debe perder su origen social, es decir, estudiamos las redes para entender el mundo y el comportamiento. En el origen está su futuro.
Julián Cárdenas

Doctor en Sociología Investigador

Freie Universität Berlín

Alemania

13 Lizardi-Gómez, A. (2010). Redes de apoyo para la atención a un padecimiento crónico en una comunidad transnacional. REDES-Revista hispana para el Análisis de redes sociales, 18, 47-82.

14 Fowler, J. H., y Christakis, N. A. (2008). Dynamic spread of happiness in a large social network: longitudinal analysis over 20 years in the Framingham Heart Study. BMJ, 337, a2338. http://doi.org/10.1136/bmj.a2338.

15 Carrington, P. J. (2011). Crime and Social Network Analysis. En J. G. Scott y P. J. Carrington (eds.), The SAGE Handbook of Social Network Analysis (pp. 236-255). London: Sage.

16 Dorussen, H., y Ward, H. (2010). Trade networks and the Kantian peace. Journal of Peace Research, 47(1), 29-42. http://doi.org/10. Coleman, J. (1988). Social Capital in the Creation of Human Capital. American Journal of Sociology, 94, 95-120. 


\section{Network analysis: definition, origins, growth and future}

\section{What is network analysis}

$\mathrm{N}$ etwork analysis or social network analysis is the solution to many problems of research. Network analysis is a theoretical and methodological approach stating that the most important thing is to study relationships, ties or contacts among actors ${ }^{1}$. Any type of relationship can be subject to network analysis: relations among individuals or organizations, communications, knowledge transfer, economic transfers and, even, neural connections.

We live in an increasingly interconnected world: we receive more e-mails today than phone calls years ago, we absorb more and more information coming from several sources. Organizations have extended through partnerships of all kinds and countries are more open and interrelated. However, our brain is not capable to record and analyze all this huge amount of relationships, contacts and ties. Think for a moment about all your co-workers, and then all the relatives of your co-workers, and then all the coworkers of the relatives of your co-workers, and the possible relationships among them. It is impossible to visualize and understand this large amount of data about people and relationships.
According to the psychologist Robin Dunbar ${ }^{2}$, our brains, despite having thousands of connections, only record 150 relationships. This 'limited' brain capacity contrasts with today's 'hyper-connected' being and, thus, analysis tools are necessary if we want to investigate the relationships among a set of actors. Network analysis is the approach that allows to process, examine and visualize a wide range of actors and possible links between them. Networks have always existed, but the way of analyzing them has not. Below are its features and some examples.

Network analysis allows, among others:

- To analyze how cohesive are the actors in one study, for example, if business elites are united or fragmented ${ }^{3}$.

- To identify who the leaders are and what position each actor occupies in the network, for example, to find out who are the middlemen in drug trafficking networks ${ }^{4}$.

- To detect subgroups or communities of actors in terms of their relationships, for example, in order to know business communities and their geographical location in the worldwide network of companies ${ }^{5}$.

- To check if relations have an impact on behavior, or what variables explain the

1 Rodríguez, J. A. (2005). Análisis Estructural y de Redes. Madrid: cis.

2 Dunbar, R. I. M. (1993). Coevolution of neocortical size, group size and language in humans. Behavioral and Brain Sciences, 16(04), 681-694. http://doi.org/10.1017/S0140525X00032325.

3 Cárdenas, J. (2015). Are Latin America's corporate elites transnationally interconnected? A network analysis of interlocking directorates. Global Networks, 15(4), 424-445. http://doi.org/10.1111/glob.12070.

4 Garay, L. J., \& Salcedo-Albarán, E. (2012). Narcotrafico, corrupcion y estados. Como las redes ilicitas han reconfigurado las instituciones en Colombia, Guatemala y Mexico. México City: Grijalbo.

5 Heemskerk, E. M., \& Takes, F. W. (2015). The Corporate Elite Community Structure of Global Capitalism. New Political Economy, 0(0), 1-29. http://doi.org/10.1080/13563467.2015.1041483. 
construction of networks, for example, if social contacts influence obesity ${ }^{6}$.

In short, network analysis answers questions involving relationships, links, contacts, transfers, infections or any type of relational pattern.

\section{Origins of social network analysis}

This theoretical and methodological paradigm stems from the contribution of various disciplines, but especially social sciences ${ }^{7}$. From psychology, Jacob Moreno ${ }^{8}$ realized the importance of social relationships among people who attended his therapies and decided to represent them as nodes and lines, creating sociograms. From anthropology, the Manchester School headed by John Barnes ${ }^{9}$ stressed the importance of networks, even over culture, in order to understand the behavior of immigrants. From sociology, Harrison White ${ }^{10}$ tried to give relational consistency to concepts such as structure, social role or market. His student Granovetter ${ }^{11}$ emphasized the importance of weak ties and insertion of economic action in social networks. Other sociologists emphasized that relations are constituents of social capital ${ }^{12}$. All these contributions of social sciences lacked a partner: graph theory of mathematics. The use of graph theory to define and analyze social networks has allowed systematic and mathematical analysis of broad sets of relationships among actors. The development of computer programs that process large amounts of data as nodes (actors) and lines (relations) has enabled researchers to answer questions about networks such as degree of cohesion or fragmentation, identification of leaders or people in power with respect to contacts, detection of internal communities, and dynamics of formation and change of networks. Network analysis has evolved from a methodological exercise to a science.

\section{Growth of network analysis}

Between 2000 and 2015, the amount of research using social network analysis has increased. According to a study of scientific articles using social network analysis, it has gone from fourteen articles in 2000 to 838 in 2014 (figure 1). In addition, since the 1990s, network analysis research has been institutionalized. There are network analysis courses at universities around the world and they are even part of the curriculum in social science programs. There are academic journals specialized in network analysis and research applying this approach, published in high impact journals. In the nineties, the International Network of Social Network Analysis was established to integrate network analysis researchers. Beyond academia, network analysis is used in the design of policies, such as scientific knowledge networks to diagnose the state of scientific production and help make decisions on research and development policies. It has been revealed that network analysis is employed by the us National Security Agency to record and analyze electronic communications, and by police departments to detect central actors in bank transfers. Organizations also use network analysis to perform internal diagnosis and get to know their environment (organizational network analysis). Although for different purposes, all these studies intend to envision and analyze sets of relations among actors, that is, networks.

\footnotetext{
6 Christakis, N. A., \& Fowler, J. H. (2007). The Spread of Obesity in a Large Social Network over 32 Years. New England Journal of Medicine, 357(4), 370-379. doi: http://doi.org/10.1056/NEJMsa066082.

7 Scott, J. (1991). Social Network Analysis. London: Sage.

8 Moreno, J. L. (1934). Who Shall Survive? Washington: Nervous and Mental Diseases Publishing.

9 Barnes, J. A. (1954). Class and committees in a Norwegian island parish. Human Relations, (7), 39-58.

10 White, H. C. (1981). Where Do Markets Come From? American Journal of Sociology, 87, 47-517.

11 Granovetter, M. S. (1973). The Strength of Weak Ties. The American Journal of Sociology, 78(6), 1360-1380.

12 Burt, R. (1982). Toward a Structural Theory of Action. Academic Press: Nueva York; Coleman, J. (1988). Social Capital in the Creation of Human Capital. American Journal of Sociology, 94, 95-120.
} 


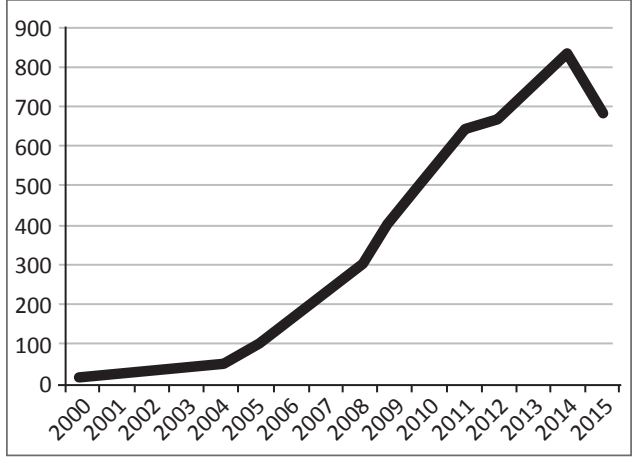

Figure 1. Scientific articles containing the keyword "social network analysis" in the abstract between 2000 and 2015. Compiled by the author based on Scopus (2016).

\section{Future of network analysis}

The future of network analysis is promising due to the rise of theories emphasizing that today's world is very interconnected, and that social relationships have an increasing impact on issues such as health ${ }^{13}$, happiness ${ }^{14}$, crime $^{15}$ and even peace ${ }^{16}$. In addition, various computer programs such as UCINET, Pajek, Gephi or R packages for network analysis allow to process large amounts of data (big data), thus meeting the demand for analysis of the vast amount of information available today. However, this advantage may also become a bad practice if not accompanied by interpretation or theory. For example, studies on Twitter conversations using network analysis have proliferated, but their results sometimes do not go beyond the mere visualization of the network and the identification of node communities. If network analysis becomes only a software tool and is not accompanied by hypothesis testing or theory generation, it will lose its essence, namely, understanding the relationships among actors. Social network analysis should not lose its social origin, that is, we study networks to understand the world and behavior. Its future lies in its inception.
Julián Cárdenas

Ph.D. in Sociology Researcher Freie Universität Berlin Germany

13 Lizardi-Gómez, A. (2010). Redes de apoyo para la atención a un padecimiento crónico en una comunidad transnacional. REDES-Revista hispana para el Análisis de redes sociales, 18, 47-82.

14 Fowler, J. H., \& Christakis, N. A. (2008). Dynamic spread of happiness in a large social network: longitudinal analysis over 20 years in the Framingham Heart Study. BMJ, 337, a2338. http://doi.org/10.1136/bmj.a2338.

15 Carrington, P. J. (2011). Crime and Social Network Analysis. In J. G. Scott and P. J. Carrington (eds.), The SAGE Handbook of Social Network Analysis (pp. 236-255). London: Sage.

16 Dorussen, H., \& Ward, H. (2010). Trade networks and the Kantian peace. Journal of Peace Research, 47(1), 29-42. http://doi.org/10. Coleman, J. (1988). Social Capital in the Creation of Human Capital. American Journal of Sociology, 94, 95-120. 